\title{
Bio-editorial: por un diálogo inter y transdicisplinar
}

DOI: http://dx.doi.org/10.18359/rlbi.1438

Durante el desarrollo del siglo xx, en el contexto académico e intelectual se agudizó la discusión entre ciencias blandas y ciencias duras; entre ciencias exactas y experimentales con las ciencias humanas, humanidades y ciencias sociales. Este hecho en la academia occidental, y más marcado en los países latinoamericanos, generó un imaginario social en el que las ciencias exactas (duras) se consideraban como aquellas que "sí" cumplían con los requisitos para ser llamadas científicas; mientras que las ciencias humanas, sociales o de humanidades se concebían como ciencias especulativas. Craso error de la sociedad académica e intelectual haber entendido las ciencias desde una clasificación y estratificación jerárquica, fenómeno que favoreció que se olvidara que tanto unas como otras producen conocimiento y han permitido la transformación y el mejoramiento en la calidad de vida de los seres humanos. Pero más que eso, se olvidaron de que la producción de sus conocimientos debía cumplir con el objetivo de proteger la sacralidad de la vida; sumado a esto, el enceguecimiento acrítico de ciencias exactas y sociales frente al sistema capitalista y de mercadeo del conocimiento es una circunstancia que en el siglo xxi es más evidente y real ${ }^{1}$.

En este contexto de la falacia dualista y fragmentaria entre ciencias duras y ciencias blandas, que para algunos aún sigue vigente, la bioética surgió como una alternativa para demostrar, tanto a científicos exactos como a científicos sociales, que una tendencia epistémica científica no es más (ni vale más) que otra. Por el contrario, se complementan, de tal forma que están llamados a generar y producir conocimiento pertinente en una sociedad convulsionada, donde la vida cada vez más está siendo afectada por avances tecno-científicos, fórmulas mercado-financieras, modelos religioso-morales, estructuras urbanístico-asfálticas, entre otros fenómenos propios de la dinámica histórica.

Plantear en pleno siglo xxi que las ciencias exactas son más que las ciencias humanas, sociales o las humanidades; o, por el contrario, sesgarse al dogmatismo radical de presentar las ciencias humanas, sociales o las humanidades como las que tienen la última palabra frente al conocimiento científico hace surgir una di-

1 Este aspecto de mercado vs. conocimiento, capitalismo vs. conocimiento, ciencia vs. producción es delicado en el contexto educativo mundial, que merece ser abordado y estudiado, pero que no es el centro de este escrito. 
cotomía entre conocimiento científico y conocimiento humanístico, que más que una confrontación invita a construir puentes de diálogo entre las ciencias, pero desde la realidad social que se suscita y gesta en cada contexto, una ciencia donde el laboratorio sea la realidad social, la cotidianidad de la vida desde su carácter holístico y no fragmentado.

El diálogo debe estar caracterizado por la apertura de mentalidad de científicos de una tendencia o de la otra; debe haber un respeto por la producción de conocimiento en cada espacio epistémico; no pensar como en épocas de antaño medievalismo que las humanidades tienen la última palabra y que las ciencias exactas deben someterse a su juicio; o no caer en la falacia de darle más valor a las ciencias experimentales denigrando el sentido de las ciencias humanísticas. El diálogo no es entre las ciencias de manera especulativa e irreal, este diálogo es entre los agentes sociales que lideran los procesos de producción de cada ciencia, es decir, los científicos, los investigadores, los académicos. Para este diálogo debe eliminarse cualquier tipo de prepotencia e ínfula porque se cree tener un saber, pues una de las condiciones naturales del diálogo es que no hay verticalidad jerárquica con poder, sino horizontalidad consensual con capacidad de escucha.

Así, en el campo de la bioética, es urgente y necesario gestar diálogos cada vez más inter y transdisciplinares, descentrándolos meramente del discurso biojurídico o biomédico, máxime cuando en el contexto actual de las ciencias y sus relaciones con la sociedad y la cultura son cada vez más interdependientes. El diálogo bioético es por excelencia un campo en el que la acción no se aplaza, en el que las ciencias humanas, sociales o las humanidades tienen un espacio de acción para sus planteamientos. De la misma manera, es el espacio donde las ciencias "exactas" pueden poner en discusión sus avances, su sentido dentro de los procesos bióticos y abióticos que nos rodean, pues al mismo tiempo este diálogo bioético es un diálogo del hombre con su entorno, cuerpo, vida, existencia, pero de manera interdependiente con la naturaleza, con el medio ambiente, con la ecología.

Podríamos hacer toda una exposición del sentido de la inter y transdisciplinariedad, de su importancia dentro de la academia, pero es importante dar el salto hacia un inter y transposicionamiento de ideas, sentimientos y pensamientos que se vuelvan acciones; pero esto es solamente posible a través del diálogo, no solo de eruditos, sino también de agentes y protagonistas sociales que se sientan miembros de un mundo interdependiente que requiere cuidado y protección. Las construcciones teóricas, académicas e intelectuales, ya sea desde las ciencias exactas o desde las ciencias humanas, deben favorecer el diálogo con todo aquello que signifique vida o permita su desarrollo. 
El diálogo bioético no puede darle la espalda a las revoluciones que acompañan a la humanidad actual: cultural, política, social, económico-financiera, ambiental, ecológica, de proliferación de géneros, médico-científica, entre otras. Por el contrario, estas revoluciones deben ser asumidas desde las ciencias construidas por el conocimiento del hombre, de manera interdependiente, ya que lo que está en medio no es la discusión de su validez o no; más bien, se trata de ver su pertinencia o no dentro de las sociedades. Para instaurar el diálogo bioético es indispensable ubicarse dentro de una sociedad líquida (Bauman), en el paradigma de la complejidad (Morin), de la filosofía de la finitud (Méllich), la sociedad del riesgo (Beck) y otro sin fin de propuestas que surgen desde las ciencias humanas y que ayudan a comprender el sentido de los avances de las hoy llamadas tecnociencias y ciencias humanísticas.

La bioética es un discurso que con su apertura y prospectiva se convierte en el escenario y terreno propicio para difundir el sentido holístico de las ciencias, de todas las ciencias sin clases sociales, es decir, es un espacio donde se cuestiona y resignifica el antropocentrismo con el que se han construido las ciencias, lo cual proyecta un establecimiento de discursos dialógicos con sentido para la realidad en la que se desarrolla la vida actualmente. La bioética, por su carácter dialógico, requiere bioeticistas abiertos al mismo diálogo académico y científico, de agentes sociales que rompan con la paradigmática actitud displicente y egocéntrica como propietarios del saber y de la ciencia, que aterricen en la realidad con la humildad del sabio, no con la prepotencia del sabelotodo. Un agente social del conocimiento con capacidad de ser interlocutor entre los fenómenos sociales, la ciencia, el ser humano, lo ecológico y todo aquello que involucre lo biótico y lo abiótico.

En este número se encuentran perspectivas bioéticas dialógicas, propuestas para entablar reflexiones desde el inicio de la vida humana, pasando por el medio ambiente y el cuidado, cimentados estos textos en ciencias médicas, humanidades, filosofía, derecho, ecología. Invitamos a que nuestros lectores y autores se motiven a conocer las tendencias actuales en bioética y para que en nuestra revista nos apoyen con artículos de investigación que aporten a responder a las necesidades de nuestra sociedad actual. La bioética no es solo biomédica o biojurídica, es también un diálogo con lo biosocial, biopolítico, bioeconómico, es decir, es un diálogo inter y transdisciplinar con todo aquello que rodea y afecta a la vida en su conjunto.

Juan María Cuevas Silva

Editor 


\section{Bio-eeditorial: an inter and transdisciplinary dialog}

DOI: http://dx.doi.org/10.18359/rlbi.1438

During the twentieth century, in the academic and intellectual context, the argument between the soft sciences and the hard science, the exact and experimental sciences with humanities and social sciences became sharper. This fact in Western academia and most marked in Latin American countries generated a social imaginary in which the exact sciences (hard) were considered as those eligible to be called scientific; whereas the human, social sciences or humanities were conceived as speculative sciences. The huge mistake of academic and intellectual society was the understanding of the sciences of a hierarchical classification and stratification, a phenomenon that favored to forget that both types produced knowledge and allowed the transformation and improvement in the quality of life of human beings. But more than that, they forgot that the production of knowledge should meet the objective of protecting the sacredness of life; Added to this, the uncritical blindness of exact and social sciences against the capitalist system and marketing knowledge is a fact that in the XXI century is more evident and real.

In this context of the dualistic and fragmentary fallacy between hard sciences and soft sciences, for some still in force, Bioethics emerged as an alternative to demonstrate both the accurate scientist and social scientist, that a scientific epistemic trend is no more (or worth) than other. On the contrary, they are complementary, so they are called to create and produce knowledge in a troubled society, where life is increasingly being affected by technoscientific developments, market and financial formulas, religious-moral models, urban-asphalt structures, among other phenomena characteristic of historical dynamics.

To come up in the XXI century that the exact sciences are more than human, social sciences or humanities; or on the other hand, biased to radical dogmatism of presenting human, social sciences or humanities as they have the last word against the scientific knowledge raises a dichotomy between scientific knowledge and humanistic knowledge that more than a confrontation invites to build a dialog between the sciences but from the social reality that arises in each context, a science where the laboratory is the social reality of everyday life from its holistic and not fragmented nature.

The dialogue should be characterized by open-mindedness of scientists of one trend or another. There must be respect for knowledge production in each epistemic 
space. Not to think as in old medievalism time that the humanities have the last word, and the exact sciences must submit to its judgment; or do not fall into the fallacy of giving more value to the experimental sciences, denigrating the meaning of the humanities. The dialogue is not between the sciences in a speculative and unreal way; this dialogue is between the social agents leading the processes of each science, that is, scientifics, researchers, and academics. For this dialogue, it should be removed any arrogance and pretentious because it is believed to have knowledge thus one of the natural conditions of the dialogue is that there no hierarchical verticality with power but horizontal consensual with listening skills.

Thus, in the field of bioethics, it is urgent and necessary to conceive dialogues increasingly inter- and transdisciplinary, put them off the center merely of the biomedical or biojuridical speech, especially when in the current context of science and its relationship with society and culture are becoming more interdependent. The bioethical dialogue is par excellence a field where the action is not postponed, in which the human, social sciences and humanities have an action space for their approaches. In the same way, it is the space where the "exact" sciences can call into question their progress, their sense of the biotic and abiotic process that surround us, because, at the same time, this bioethical dialogue is a dialogue between man and his environment, body, life, existence, but in an interdependent way with nature, environment, and ecology.

We could do a big argument about the sense of the inter- and transdisciplinary, their importance within the academy. But it is important to leap towards inter and transposition of ideas, feelings and thoughts that become actions; but this is only possible through dialogue, not only scholars but also agents and social players that feel the membership of an independent world that requires care and protection. The theoretical, academic and intellectual constructions, either from the exact sciences or humanities, should encourage dialogue with everything that means life or allows its development.

The bioethical dialogue cannot turn its back to the revolutions that accompany humanity today: cultural, political, social, economic, financial, environmental, ecological, proliferation of genres, medical and scientific, among others. On the contrary, these revolutions should be taken from the sciences built by the knowledge of men, interdependently, since what is in the middle is not the discussion of its validity, rather, it is seeing its relevance or not within societies. To introduce the bioethical dialogue is essential to be placed in a liquid society (Bauman), in the paradigm of complexity (Morin), philosophy of finitude (Méllich), the risk society (Beck) and a myriad of proposals arising from the human sciences and to help make sense of the progress of calls today technoscience and humanities. 
Bioethics is a speech that with its opening and prospective becomes the stage and ground for spreading the holistic sense of the science, of all sciences without social classes, this is a space where questions and redefines anthropocentrism with which they have been built sciences, which projects a dialogic setting meaningful speeches to the reality in which life develops today. Bioethics, because of its dialogic nature, requires open bioethicists at the same academic and scientific dialogue, social agents that break with the paradigmatic complacent and self-centered attitude as owners of knowledge and science, landing at reality with the humility of the wise, not with arrogance Smarty. A social agent capable of being knowledge interlocutor between social phenomena, science, human, ecological and everything that involves the biotic and abiotic.

In this issue, we found dialogic bioethical perspectives, proposals to engage reflections from the beginning of human life, including the environment and care, these texts grounded in medical sciences, humanities, philosophy, law, ecology. We invite our readers and authors to motivate to meet current trends in bioethics and to support us in our magazine research with articles that contribute to meet the needs of our society. Bioethics is not only biomedical or Biojuridical, but is also a dialogue with biosocial, biopolitical, bio-economic, in other words, it is also an inter- and transdisciplinary dialogue with everything that surrounds and affects life as a whole.

Juan Maria Cuevas Silva

Editor 


\section{Bio-editorial: por um diálogo inter e transdisciplinar}

DOI: http://dx.doi.org/10.18359/rlbi.1438

Durante o desenvolvimento do século XX, no contexto acadêmico e intelectual agudizou-se a discussão entre as ciências macias e ciências duras; entre ciências exatas e experimentais com as ciências humanas, humanidades e ciências sociais. Este fato na academia ocidental, e mais acentuada nos países latino-americanos, gerou um imaginário social no qual as ciências exatas (duras) consideravam-se como aquelas que "sim" eram as que cumpriam com as condições para serem chamadas de científicas; no entanto que as ciências humanas, sociais ou de humanidades foram concebidas como ciências especulativas. Crasso erro da sociedade acadêmica e intelectual ter entendido as ciências desde uma classificação e estratificação hierárquica, um fenômeno que favoreceu a que se esqueceram que tanto umas como as outras produzem conhecimento e tem permitido a transformação e melhoramento na qualidade de vida dos seres humanos. Mas mais do que isso, se esqueceram de que a produção de seus conhecimentos devia cumprir com objetivo de proteger a sacralidade da vida; somado a isso, a cegueira acrítica de ciências exatas e sociais perante o sistema capitalista e de comercialização do conhecimento é uma circunstância que no século XXI é mais evidente e reall ${ }^{1}$.

Neste contexto da falácia dualista e fragmentada entre ciências duras e ciências macias, que para alguns ainda segue em vigor, a bioética surgiu como uma alternativa para demonstrar, tanto para os cientistas exatos como a cientistas sociais, que uma tendência epistêmica científica não é mais (nem vale mais) do que a outra. Pelo contrário, são complementares, de forma tal que são chamados a gerar e produzir conhecimento relevante em uma sociedade conturbada, onde a vida é cada vez mais afectada por avanços técnico-científicos, fórmulas mercado-financeiras, modelos religioso-morais, estruturas urbanistico-asfalticas, entre outros fenómenos característicos da dinâmica histórica.

Considerar no século XXI que as ciências exatas são mais do que as ciências humanas, sociais ou as humanidades; ou, pelo contrário, ter tendência ao dogmatismo radical

1 Este aspecto do mercado vs. conhecimento, capitalismo vs. conhecimento, ciência vs. produção é uma questão sensível no contexto educacional global, que deve ser abordado e estudado, mas que não é o centro deste escrito. 
de apresentar às ciências humanas, sociais ou as humanidades, como aquelas que têm a última palavra perante o conhecimento científico, faz surgir uma dicotomia entre o conhecimento científico e o conhecimento humanístico, que mais que um confronto convida à construção de pontes de diálogo entre as ciências, mas a partir da realidade social que surge e se gesta em cada contexto, uma ciência onde o laboratório é a realidade social cotidianidade da vida desde seu caráter holístico e não fragmentado.

O diálogo deve ser caracterizado pela abertura da mentalidade dos cientistas de uma tendência ou da outra; deve haver um respeito para a produção de conhecimento em cada espaço epistêmico; não pensar como nos tempos de outrora medievalismo que as humanidades têm a última palavra e que as ciências exatas devem-se submeter ao seu juízo; ou não cair na falácia de dar mais valor às ciências experimentais denegrindo o significado das ciências humanísticas. O diálogo não é entre as ciências de maneira especulativa e irreal, este diálogo é entre os agentes sociais que lideram os processos de produção de cada ciência, quer dizer, os cientistas, os pesquisadores, os acadêmicos. Para este diálogo deve-se eliminar qualquer tipo de prepotência e pretensões porque se acredita ter um conhecimento, pois uma das condições naturais do diálogo é que não existe verticalidade hierárquica com poder, mas sim horizontalidade consensual com capacidade de escuta.

Assim, no campo da bioética, é urgente e necessário gestar diálogos cada vez mais inter e transdisciplinares, descentrando-os meramente do discurso bio-jurídico ou biomédico, especialmente quando no contexto atual das ciências e suas relações com a sociedade e a cultura estão se tornando cada vez mais interdependentes. O diálogo bioético é por excelência um campo onde a ação for adiada, na qual as ciências humanas, sociais ou as humanidades têm um espaço de ação para as suas abordagens. Da mesma forma, é o espaço onde as ciências "exatas" podem pôr em causa o seu progresso, o seu sentido dentro dos processos bióticos e abióticos que nos rodeiam, porque enquanto este diálogo bioético é um diálogo entre o homem e seu ambiente, corpo, vida, existência, mas de forma interdependente com a natureza, com o meio ambiente, com a ecologia.

Nós poderíamos fazer uma exposição de significado da inter e transdisciplinaridade, de sua importância dentro da academia, mas é importante dar o salto em direção inter e transposicionamiento de ideias, sentimentos e pensamentos que se tornam ações; mas isso só é possível através do diálogo, não só de eruditos, mas também de agentes e protagonistas sociais que se sintam membros de um mundo interdependente que requer cuidado e proteção. As construções teóricas, acadêmicas e intelectuais, seja desde as ciências exatas ou desde as ciências humanas, devem promover o diálogo com tudo o que significa a vida ou a permitir o seu desenvolvimento. 
O diálogo bioético não pode virar as costas às revoluções que acompanham à humanidade atual: culturais, políticos, sociais, econômico-financeiro, ambientais, ecológicos, de proliferação de gêneros, médico-científico, entre outras. Pelo contrário, essas revoluções devem ser aceitas desde as ciências construídas pelo conhecimento do homem, de forma interdependente, uma vez que o que está no meio não é a discussão sobre a sua validade ou não; em vez disso, está-se vendo sua relevância ou não dentro das sociedades. Para introduzir o diálogo bioético é essencial posicionar-se dentro de uma sociedade líquida (Bauman), no paradigma da complexidade (Morin), da filosofia da finitude (Méllich), sociedade do risco (Beck) e uma miríade de propostas que surgem a partir das ciências humanas e que ajudam a compreender o sentido do progresso das chamadas hoje tecno-ciências e ciências humanísticas.

A bioética é um discurso que com sua abertura e prospectiva torna-se no cenário e terreno favorável para espalhar o sentido holístico das ciências, de todas as ciências sem classes sociais, quer dizer, é um espaço onde se questiona e redefine o antropocentrismo com aquele que tem sido construídas as ciências, o qual projeta um estabelecimento de discursos dialógicos significativos para a realidade em que a vida se desenvolve atualmente. A bioética, por seu caráter dialógico, requer bioeticistas abertos ao mesmo diálogo acadêmico e científico, de agentes sociais que rompam com a paradigmática atitude displicente e egocêntrica como proprietários do conhecimento e da ciência, que a tragam para a realidade com a humildade dos sábios, não com a arrogância daquele que crê sabê-lo todo. Um agente social do conhecimento com capacidade de ser o interlocutor entre os fenômenos sociais, a ciência, o ser humano, o ecológico e tudo o que envolve o biótico e abiótico.

Nesta edição encontram-se perspectivas bioéticas dialógicas, propostas para estabelecer reflexões a partir do início da vida humana, passando pelo meio ambiente e o cuidado, estes textos encontram-se fundamentados em ciências médicas, humanidades, filosofia, direito, ecologia. Convidamos os nossos leitores e autores a serem motivados a conhecer as tendências atuais em bioética e para nos apoiar em nossa revista com artigos de investigação que contribuam para satisfazer as necessidades de nossa sociedade atual. A bioética não é só biomédica ou biojurídica, é também um diálogo com o biossocial, biopolítico, bio-econômico, ou seja, é um diálogo inter- e transdisciplinar e com tudo o que envolve e afeta a vida como um todo.

Juan María Cuevas Silva

Editor 